\title{
Microscopic examination of chops with content of lentil flour
}

\section{Iryna Simonova ${ }^{1}$, Liudmyla Peshuk ${ }^{2}$, Oleg Galenko}

\author{
1 - Stepan Gzhytskyi National University of Veterinary Medicine and Biotechnologies, \\ Lviv, Ukraine \\ 2 - National University of Food Technologies, Kyiv, Ukraine
}

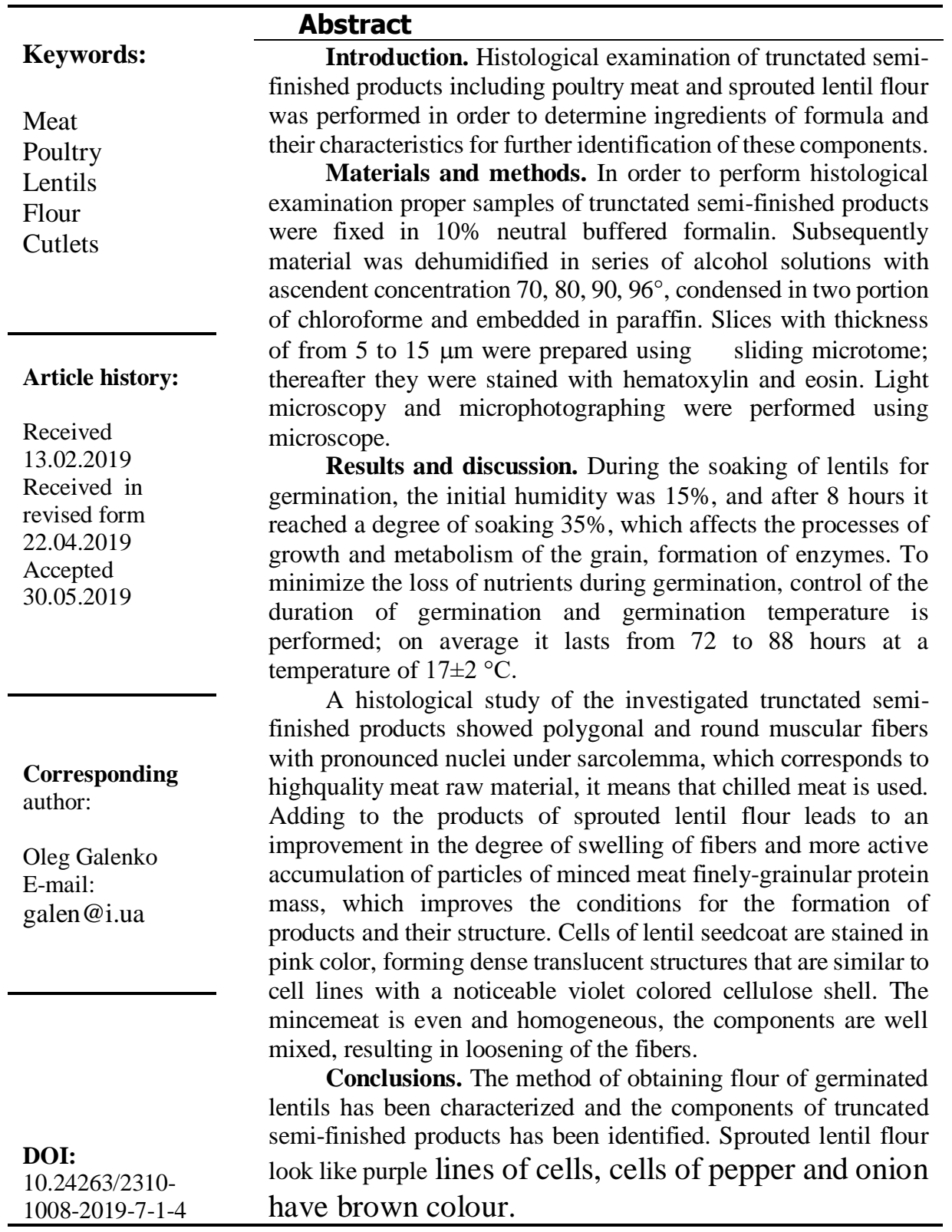




\section{Introduction}

In the era of modern technologies in manufacturing of truncated semi-finished products, the adaptation of recipes using meat and vegetable raw materials is important. [1] Most food producers refuse to manufacture products in accordance with State standards, but develop and approve their assortment in accordance with the specifications of requirement [2]. Lack of supply of farm animals meat and the import of frozen meat prompts the development of technologies for truncated semi-finished products with a combined composition of meat and vegetable raw materials [3].

\section{Literature review}

Current issues of the present remain the use of poultry meat as sources of valuable protein and in comparison with other types of meat, less valuable raw materials. There are known technologies of production of truncated semi-finished products with poultry meat mechanical deboning. It also receives protein-mineral nutritional supplements that are used in cooking potatoes and schnitzels $[4,5]$.

The composition of the recipes of many meat products includes soy. The content of protein in soybean seeds, which yields soy flour, ranges from 30 to $45 \%$ on average. However, there is a lot of information on the harm to human health of genetically modified organisms, which include soy [6, 7, 8, 9].

An alternative to soya is lentil. By its content, lentil protein is also ahead of peas and beans. Protein lentils, like other leguminous cultures, is rich in the most important essential amino acids that are necessary for the human body, lysine, tryptophan, valine, arginine, and others. In almost all grain legumes contain various anti-nutrients (enzyme inhibitors, in particular trypsin, alkaloids, etc.). Most of these substances have protein origin, they can be inactivated by thermal treatment [10].

It should also be noted that during heat treatment the beneficial properties of lentils are completely preserved. In addition to high protein content $(25 \ldots 50 \%)$, different varieties of lentils contain about $50 \%$ of carbohydrates, $2-4 \%$ of minerals, $1-3 \%$ of fat. In comparison with lentil, soya contains up to $26 \%$ fat. It should be emphasized that lentil is a source of vitamins $B$ (thiamine, riboflavin, niacin), $\beta$-carotene, minerals such as sodium, potassium, calcium, magnesium, phosphorus, iron, amino acids and protein which are easily digestible by the human body [11].

The use of lentil flour in combination with meat makes it possible to form a stable system that can withstand weakly bound water and fat during heat treatment, and thus obtain the finished products of a dense and elastic consistency [12].

The use of plant material in the production of meat semi-finished products does not require additional complex processes, ensures compliance with traditional technological schemes of production and cheapening finished products [13].

As a result, the quality control of meat products remains topical. In order to detect various components that are part of meat products, methods of histological analysis are widely used $[14,15]$. These methods are based on the microstructure and chemical properties of the components. This allows using a special differential coloring to detect all components of the recipe during a microscopic study $[16,17]$.

Abdel Hafeez H.H., Zaki R.S. Abd El-Magiud DS have done a research or the purpose of revealing the components that are included in the recipes of meat products by means of histological analysis. They found that in the composition of many sausages and chops used 
for hot dogs and hamburgers is also place for meat with a large amount of connective tissue, tendons, byproducts, soy and other vegetable raw materials [18].

R. Latorre, J. Sadeghinezhad, B. Hajimohammadi, F. Izadi, M.T. Sheibani during histological studies found components of the meat products not mentioned on the marking, namely, connective tissue and fat tissue, stomach and cartilage tissues [19].

In the writings of Guelmamene R. Bennoune O. Elgroud R. special attention is paid to the histological study of meat and meat products with the discovery of their mechanical deboned meat, twice frozen meat, and the presence of meat with signs of damage. This allows us to conclude that the effectiveness of using this method is not only to identify signs of falsification, but also to confirm the quality and safety of the product [20].

On the basis of morphological peculiarities of structures, it is possible to quantify the available components in truncated semifinished products. This prevents possible falsification of these products [21].

When conducting research, important attention should be paid to the peculiarities of the technological process of truncated semifinished products, as the technological process consists of the preparation of raw materials, preparation of minced meat. All components are weighed or dispensed with dispensers. Weighed raw materials and spices are loaded into a continuous-action mixer or continuous-action aggregates, in which the minced meat is prepared, and stirred for 4 to 6 minutes, cutlery machines are used for the formation of semifinished products [22]. Then they carry out packaging, marking and storage of finished products. Therefore, working with biological tissues in food products has certain specifics compared with native tissues, because in this case the material is subject to research after mechanical, thermal and other treatments [22].

The scientific value of the research results is the identification of quality meat, lentil flour, spices in chops by the histological method, which is effective for qualitative and quantitative analysis of minced meat and the detection of possible falsification of the data of the recipe components.

The aim of the work is to determine the microstructure of the branched semi-finished products, to identify the individual components of the recipe, give their characteristics for further identification of these components.

The main task is to characterize the method of obtaining flour sprouted lentils; identify the components of cut semi-finished products.

\section{Materials and methods}

\section{Materials}

Recipes have been developed for researches of semi-finished products, namely, chops, which are chilled or frozen semi-finished product containing meat raw materials in accordance with a recipe of not less than $50 \%$, an oval, oval-flattened form having a mass of $50 \mathrm{~g}$ to $100 \mathrm{~g}$ in breadcrumbs.

In the recipe of the half-finished semifinished products, beef meat was replaced by pork meat, goose, chicken, wheat flour bread on lentil flour, and instead of breading with wheat breads, corn grits were used. From the experimental recipes, melange and unsalted fat have not been removed. Number of onions has been increased from 2 to $4 \mathrm{~kg}$ per $100 \mathrm{~kg}$, in order to improve the organoleptic characteristics of semifinished products. The amount of added salt and black pepper has not changed. 


\section{Food Technology}

Chops with the recipes of which include first-class beef, semi-lean pork, wheat flour bread, wheat bread for panning have been taken for a control sample . Preparation of semifinished products is carried out in accordance with the general technology.

\section{Getting lentil flour}

Getting the flour of germinated lentils is to wash the grains with running water, soaking the grains in a water reservoir at a temperature of $18 \pm 2 \square \mathrm{C}$ for 8 hours, re-washing, sprouting lentil grains in a reservoir without water at a temperature of $17 \pm 2^{\circ} \mathrm{C}$ for 3 days to the length of the $1 \mathrm{~cm}$ steer, drying the raw material to a moisture content of $16 \%$ and chopping up to a particle size of $0.2 \mathrm{~mm}-0.4 \mathrm{~mm}$. The size of the particles of the flour is determined by sifting it through a sieve with a passage of $0.2 \mathrm{~mm}$ to $0.4 \mathrm{~mm}$ grating openings [12].

The moisture content of lentils was determined using the SuperPoint grain moisture meter, which is used for rapid analysis of grain moisture in laboratory and field conditions. To measure the grain humidity, the appliance is switched on, the name of the scale of the corresponding measuring crop or product is selected on the LCD screen, the necessary sample is selected, which falls into the device, the pressure cover of the pressurizes to the level until the pressure indicator is set to the level with the upper surface of the lid. After tightening the button "TEST" is pressed and after 10 seconds the result of the measurements of humidity in $\%$ is received. Measurement is carried out with an accuracy of $0.5 \%$ with a range of humidity measurement from 8 to $45 \%$.

\section{Research methodology}

For histological examination in samples with uniform distribution of components, fragments from different sites were taken - a cube or a plate 1-1.5 cm thick was cut out. Prepared samples of the chops were fixed in a $10 \%$ neutral solution of formalin. For this purpose, an ordinary method of making slices is used, which begins with the fixation of the material. All investigated semi-finished products were fixed for 24-48 hours at room temperature $\left(15-20^{\circ} \mathrm{C}\right)$ in a $10 \%$ solution of formalin. After a certain period of time, the material was taken out of formalin, washed with running water, dehydrated, using the traditional method using alcohols of ascending concentration [14,16].

The next step was paraffin filling. After that, the fixed material was dehydrated in a number of solutions of alcohol at concentrations of $70,80,90,96^{\circ}$, densified in two portions of chloroform and poured into paraffin. Depending on the type of meat product, the filling time of the material may be different. The production of paraffin blocks from semi-finished products lasted up to 48 hours $[14,16]$.

After receiving paraffin blocks, the histological sections were made on the slegde the microtome, from 5 microns to 15 microns thick, they were fixed on a specimen glass and stained with hematoxylin and eosin for 10 to 15 minutes. Light microscopy and microphotography of histoparticles were performed using an OLYMPUS CX 41 microscope and a OLYMPUS C-5050 camera [14,16]. 


\section{Food Technology}

\section{Results and discussion}

\section{Characteristics of lentil during germination and flour production}

Since lentil contains oligosaccharides and high-polymeric protein structures that affect the digestion and absorption of the product, their negative effects can be reduced by germination. When lentils are soaked, water penetrates into the embryo of the grain, and then through the side shells in the grain. Water absorption capacity depends on the duration of soaking, temperature, grain size.

During the soaking of lentils, absorption of moisture does not occur exactly as the rapid and even moisture of the floury body, as the distribution of water is uneven. The initial moisture content of lentils was $15 \%$, and after 8 hours it reached a degree of soaking 35\%, which affects the processes of growth and metabolism in the grain, as well as the formation of enzymes. Excessive water absorption of the grain leads to the death of the embryo.

To minimize the loss of nutrients during germination, the duration of germination and germination temperature must be contolled, which is $17 \pm 2^{\circ} \mathrm{C}$. The duration of germination is achieved when the length of the sprout reaches $1 \mathrm{~cm}$, which on average lasts from 72 hours to 88 hours. According to the scientific literature [23], under such conditions, the maximum accumulation of extractives is up to $29.9 \mathrm{mg} / 100$, the maximum yield of sprouted grains of lentils at given technological parameters is $92 \%$, and the loss of germinated sprouts is reduced.

The germination is completed by removing drying water, which prevents further growth of the embryonic roots. As a result of heat exposure during drying, most embryos die, so drying was carried out in the dryer at a temperature not exceeding $30^{\circ} \mathrm{C}$. Simultaneously with the termination of germination, the dissolution ends and further processes of splitting cease.

The grinding of lentil grain was carried out using laboratory mills LMT 2, OS 124, where all the components of the grain are ground evenly to obtain a homogeneous mixture. The size of the flour particles passing through sieve is $0.2 \mathrm{~mm}-0.4 \mathrm{~mm}$. When adding lentil flour to the minced meat, its interaction with water and hydration occurs, swelling and peptization of high-molecular organic compounds of flour occurs too. By absorbing water osmotically, the protein molecule of flour is significantly increased in volume. During the addition of minced meat as a result of the mechanical action, the swollen particles of proteins stick together and form a structure that provides minerals of plasticity.

\section{Histological studies of truncated semi-finished products}

The histological study of experimental samples revealed polygonal and round muscular fibers with pronounced sarcoma nuclei. This is due to the fact that meat raw materials are of high quality, obtained from chilled meat (Figure 1). Compared with the data of Sadeghinezhad J., in which the histological method was mainly used to detect fresh and defrosted pork meat, ice crystals and changes in muscle fiber were not detected in experimental samples of the chops [24]. 


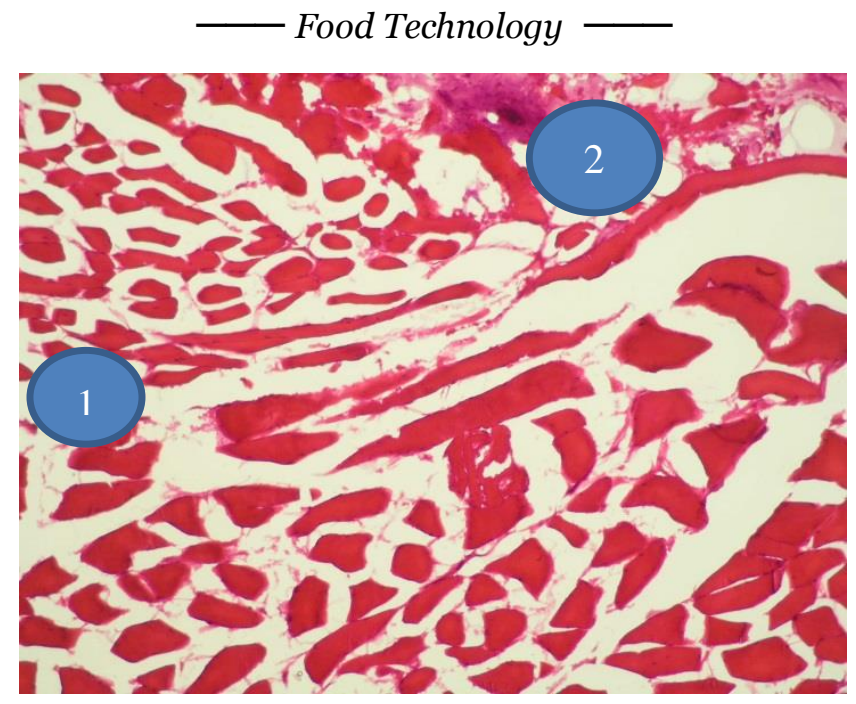

Figure 1. Chops control sample

(Hematoxylin and eosin, Eyepiece 10, lens $20 \times 100$ )

Hajimohammadi B, Izadi F found animal and vegetable components, namely, transverse sections of the striped skeleton, dense connective tissue and smooth stomach muscles, cotyledonous soybean cells, soy extrudate in the studies of minced meat [25]. In contrast, experimental samples are made without the use of soy, and beef meat is replaced by poultry meat.

The conformity of components of the recipe of their composition is established.In the control sample, oval cells of adipose tissue (1), visible onions, black pepper, painted in brown (2) are observed.

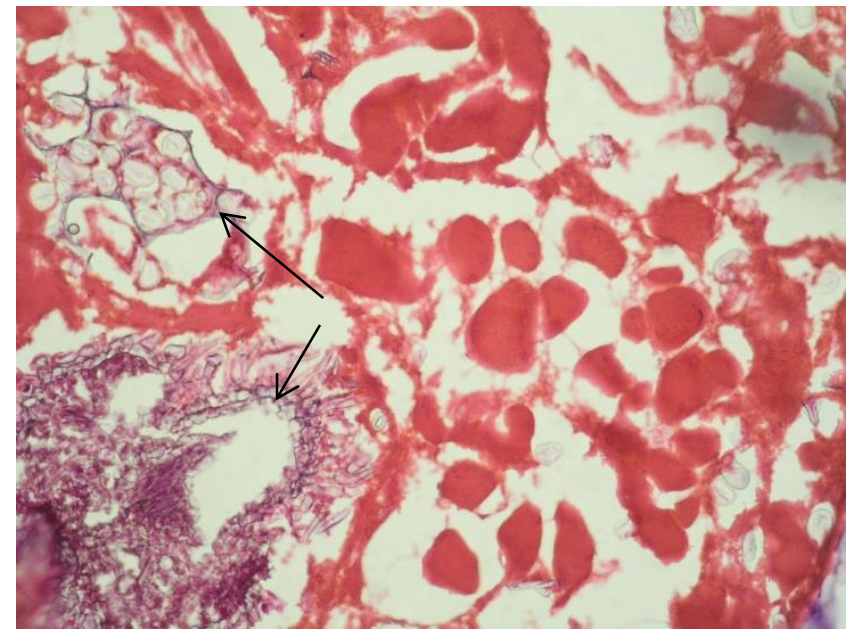

Figure 2. Chops control sample

(Hematoxylin and eosin, Eyepiece 10, lens $20 \times 100$ ) 


\section{- Food Technology}

The recipe of the control sample includes bread made from wheat flour, shown in Figure 2 with brown fibers (shown with arrows).

Cells shell flour lentils are painted in pink color, forming dense translucent structures that resemble a thread of cells with a noticeable purple shell of cellulose. Picture 3 shows the arrows.

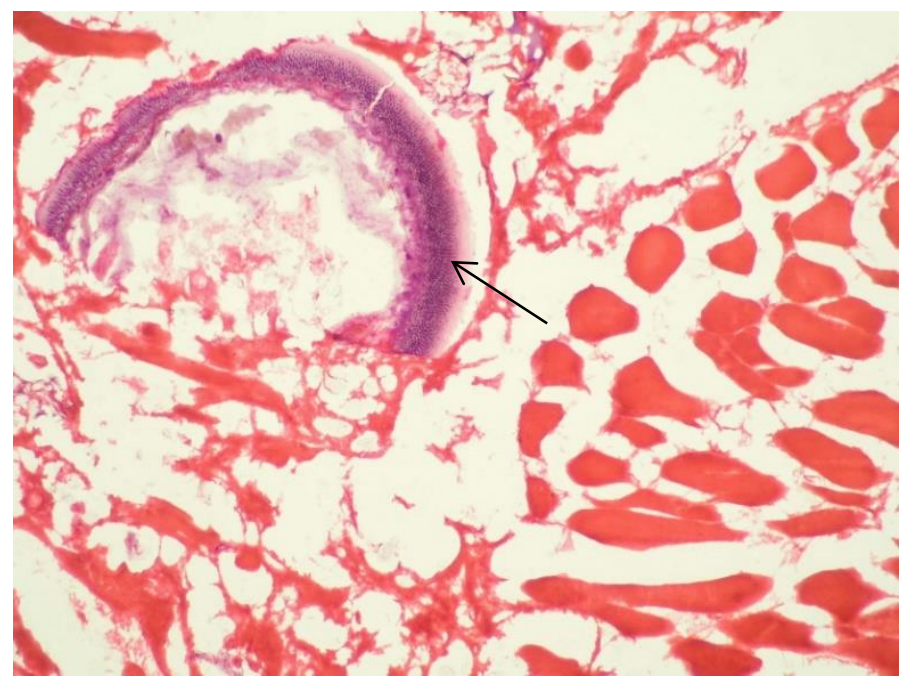

Figure 3. Chops sample with the usage of lentil flour sprouted (Hematoxylin and eosin, Eyepiece 10, lens $20 \times 100$ )

Meat products with the usage of soy flour are identified as a group of cells with a pronounced eosinophilic cytoplasm, and the cells themselves are separated by non-painted layers of cellulose (Figure 4) [14].

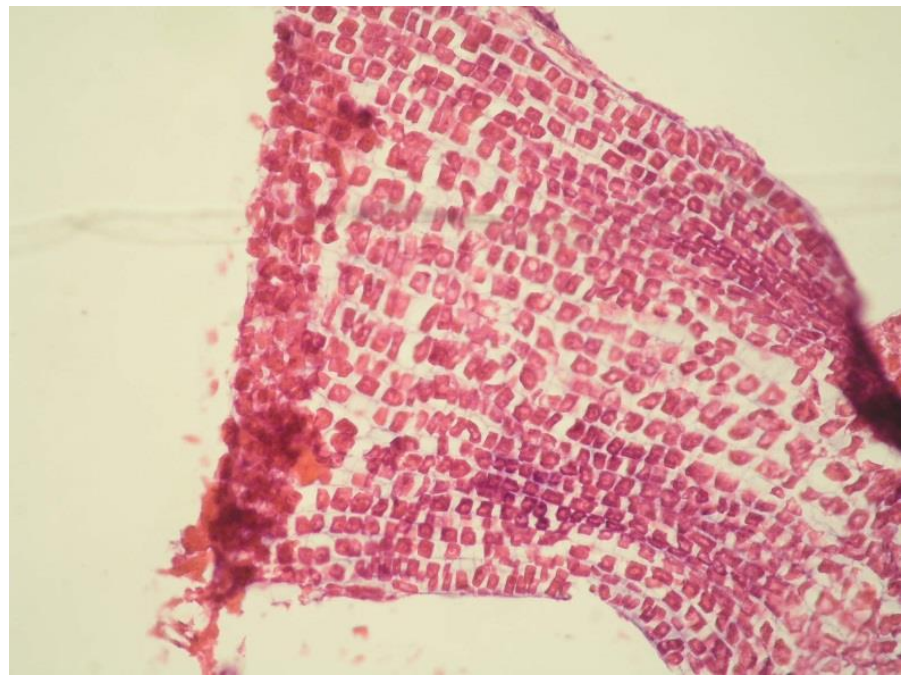

Figure 4. Sample of meat products using soy flour (Hematoxylin and eosin, ocular 10, lens $40 \times$ 50) $[14]$ 
Jahed-Khaniki GR was involved in the identification of frozen raw materials and soybeans in hamburgers by the histological method [26]. In contrast to these studies, the difference between the cells of lentil flour in experimental chops and soy flour cells is in the size, shape and number of constituents of soy flour cells. This is due to the fact that the accumulation of its cells can count cells as the same type, and with different morphological structure (rounded, oval-cylindrical).

Adding to the products of lentil flour, germinated, leads to an improvement in the degree of swelling of fibers and more active accumulation of fine particles of fine-grained protein mass, which improves the conditions for the formation of products and their structure (Figures 5-6).

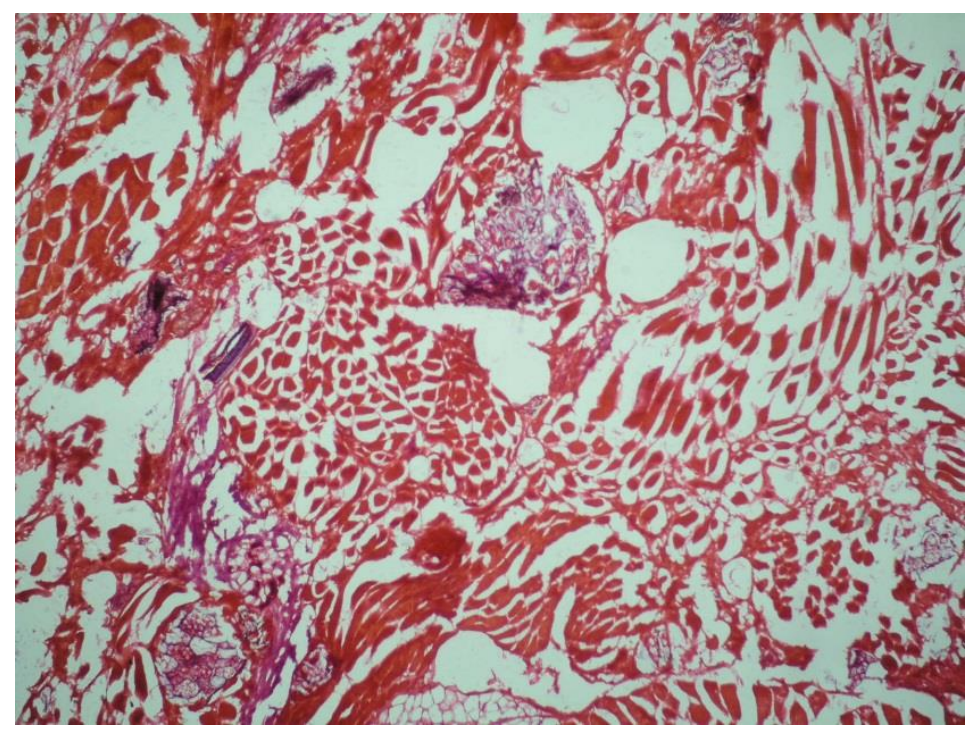

Figure 5. Sample number 2 using flour sprouted lentil, added in the amount of $10 \mathrm{~kg}$ per $100 \mathrm{~kg}$ (Hematoxylin and eosin, Eyepiece 10, lens $20 \times 100$ )

There is the inclusion of particles of lentil flour in all new experimental samples of the chops. Minced meat structure is even and homogeneous, the components are well mixed, resulting in loosening of the fibers.Unlike research on hamburgers, Abbasy-Fasarani M, containing 30 and $60 \%$ of meat [27], experimental samples of the chops are produced without deviations from the recipe. Histological studies confirm the meat content of the product not less than $50 \%$. 


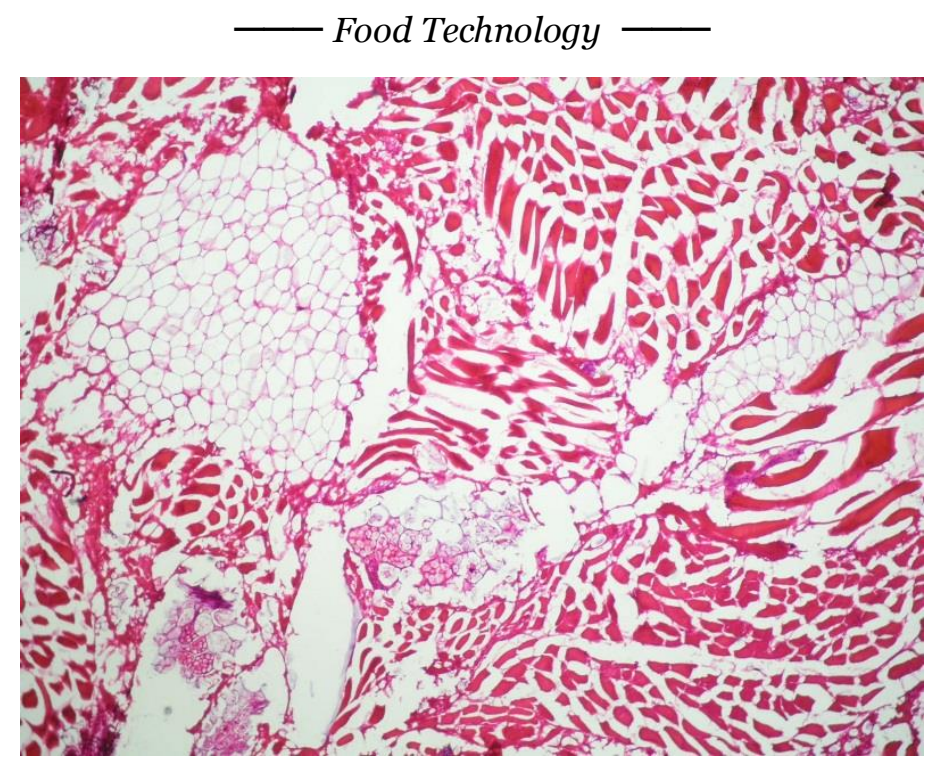

Figure 6. Sample number 3 using flour of germinated lentils added in the amount of $12 \mathrm{~kg}$ per $100 \mathrm{~kg}$

(Hematoxylin and eosin, Eyepiece 10, lens $20 \times 100$ )

Figure 6 shows the fraction of the test sample with the presence of acute muscle fibers, mesh cells of adipose tissue, brown colored cells, confirming the presence of black pepper. This is due to the use of poultry meat, semi-fat pork and lentil flour in a recipe amounting to $12 \mathrm{~kg}$ per $100 \mathrm{~kg}$ of raw meat material.

\section{Conclusion}

1. Lentil sprouting provides a reduction in the negative effects of oligosaccharides and highpolymer protein structures on the digestion and assimilation of the product. The germination time is from 72 to 88 hours.

2. During the histological studies, it was established that the amount of meat in the experimental samples of truncated semifinished products (cjops) is not less than $50 \%$. The ingredients of the recipe are evenly mixed, the lentil flour of germinated has the form of filament of purple-colored cells, pepper and onion seeds are painted in brown color.

\section{References}

1. Markovych I.I. (2015), Vplyv priano-aromatychnoi syrovyny na yakist tvarynnykh zhyriv, Skhidnoievropeiskyi zhurnal peredovykh tekhnolohii, 2/10(74), pp. 31-36.

2. Taran T.V., Ushakov O.F. (2016), Mikrostrukturnyi analiz kovbasnykh vyrobiv, Scientififc reserches and their practical application. Modern state and ways of development, 10, pp. 47-55.

3. Peshuk L.V., Galenko O.O., Budnik N.V. (2014), Use of collagenase in technology gerodietetic products, Journal of food and packing science, technique and technologies, 2(3), pp. 8-11. 
4. Topchii O.A., Peshuk L.V. (2007), Vykorystannia netradytsiinoi syrovyny v kombinovanykh miasnykh napivfabrykatakh, Naukovi pratsi NUKhT, 2, pp. 51-57.

5. Peshuk L.V., Hashchuk O.I., Moskaliuk O.I. (2015), Innovatsiinyi miasnyi produkt, Kharchova promyslovist, 17, pp. 64-67.

6. Mao L., Wang W., Tai K., Yuan F., Gao Y. (2017), Development of a soy protein isolate-carrageenan-quercetagetin non-covalent complex for the stabilization of $\beta$ carotene emulsions, Food Funct., 25, pp. 40-45, DOI:10.1039/c7fo01238a.

7. Sumczynski D., Bubelova Z., Sneyd J., Erb-Weber S., Mlcek J. (2015), Total phenolics, flavonoids, antioxidant activity, crude fibre and digestibility in non-traditional wheat flakes and muesli, Food Chem., 174, pp. 319-25, DOI:10.1016/j.foodchem.2014.11.065.

8. Caparros, Megido R., Alabi T., Nieus C. et al. (2016), Optimisation of a cheap and residential small-scale production of edible crickets with local by-products as an alternative protein-rich human food source in Ratanakiri Province, Cambodia. J. Sci. Food Agric, 96(2), pp. 627-32, DOI:10.1002/jsfa.7133.

9. Souza P.M., Bittencourt M.L., Caprara C.C., et al. (2015), A biotechnology perspective of fungal proteases, Braz J Microbiol, 46(2), pp. 337-46, DOI:10.1590/S1517838246220140359.

10. Markovych I.I. (2014), Doslidzhennia amino kyslotnoho skladu napivkopchenykh kovbas z vykorystanniam sochevytsi yalivtsiu ta chebretsiu, Skhidnoievropeiskyi zhurnal peredovykh tekhnolohii, 6/10(72), pp. 38-44, DOI: 10.15587/17294061.2014.28725.

11. Drachuk U., Simonova I., Halukh B., Basarab I., Romashko I. (2018), The study of lentil flour as a raw material for production of semi-smoked sausages, Easterneuropean journal of enterprise technologies, 6/11(96), pp. 44-50, DOI:10.15587/17294061.2018.148319.

12. Markovych I. I. (2015), Doslidzhennia zhyrnokyslotnoho skladu napivkopchenykh kovbas z vykorystanniam sochevytsi, yalivtsiu ta chebretsiu, Kharchovanauka i tekhnolohiia, 1(30), s. 37-42.

13. Hrehircha N.M., Peshuk L.V., Zusko K.V. (2017), Doslidzhennia sosysok z vkliuchenniam kvertsetynu i natyvnoi kvertsetynvmisnoi syrovyny podovzhenoho terminu zberihannia, Naukovi pratsi NUKhT, 23(4), pp. 223-230.

14. Shchebentovska O.M. (2014), Suchasni metody vyiavlennia ta identyfikatsii bilkivsoi u miasnykh vyrobakh, Naukovo-tekhnichnyi biuleten Instytutu biolohii tvaryn $i$ Derzhavnoho naukovo-doslidnoho controlnoho instytutu vetpreparativ ta kormovykh dobavok, 15(1), pp. 239-245.

15. Ince E., Özfiliz N. (2018), Detection of adulterations in fermented and heat-treated Turkish type sau-sages by histological examination. Ankara Üniversitesi Veteriner Fakültesi Dergisi, 65(1), pp. 99-107, DOI:10.1501/vetfak_0000002834.

16. Iesina E.V., Martseniuk I.V. (2010), Osoblyvosti provedennia mikrostrukturnoho doslidzhennia vyrobiv, Visnyk Dnipropetrovskoho Derzhavnoho Ahrarnohouniversytetu, 1, pp.114-119.

17. Peshuk L.V., Galenko O.O., Budnik N.V. (2011), Gerodietic meat products technology enriched with calcium and phosphorus, Journal of Faculty of Food Engineering, Ştefancel Mare University-Suceava, pp. 1-8.

18. Abdel Hafeez H.H., Zaki R.S., Abd El-Magiud D.S. (2016), Applying light, histochemical and scanning histological methods forthe detection of unauthorized animal and herbal content in street meat sandwich: what is in the sandwich we eat, 
Journal of Food Processing \& Technology, 7, pp. 12-17, DOI: 10.4172/21577110.1000643.

19. Latorre R., Sadeghinezhad J., Hajimohammadi B., Izadi F., Sheibani M.T. (2015), Application of morphological method for detection of unauthorized tissues in processed meat products, Journal of Food Quality and Hazards Control, 2, pp. 71-74.

20. Guelmamene R., Bennoune O., Elgroud R. (2018), Histological techniques for quality control of meat and meat products - A mini-review, J Nutr Hum Health, 2, 2, pp. 24 29.

21. Vanha G., Kvasnicka F. (2011), Methods of detecting plant raw materials in meat products - a review, Czech J. Food Sci, 29, pp. 471-479.

22. Peshuk L.V., Salov K.M., Halenko O.O. (2011), Tekhnolohiia nutrientno-adekvatnykh produktiv $\mathrm{z}$ vykorystanniam netradytsiinoi syrovyny $\mathrm{u}$ herodiietychnomu kharchuvanni, Kharchova nauka i tekhnolohiia, 2, pp. 8-12.

23. Telezhenko L.M., Atanasov V.V. (2013), Obhruntuvannia tekhnolohichnykh pidkhodiv kompleksnoi pererobky sochevytsi, Kharchova nauka i tekhnolohiia, 4 (25), pp. 77-80.

24. Radzievska I., Melnyk O., Galenko O., Peshuk L. (2018), Two-stage technology for palm oil fractionation for production of cocoa butter substitutes, Nauka innov. 2018, 14(1), pp. 40-49.

25. Sadeghinezhad J., Izadi F., Latorre R. (2016), Application of histomorphological method to assess meat products: A Case Study, Anatomical Sciences, 13(2), pp. 79-84.

26. Jahed-Khaniki GR, Rokni N. (2004), Histological detection of soya in freezing raw hamburger of Iran (Persian), Animal Sciences (Pajouhesh\&Sazandegi), 62(1), pp. 7175.

27. Abbasy-Fasarani M., Hosseini H., Jahed-Khaniki GR, Adibmoradi M., Eskandari S. (2012), Histological study of industrial hamburgers containing 30 and 60 percent meat for presence of unpermitted edible tissues and correlation of this factor to meat connective tissue chemical indices (Persian), Iranian Journal of Nutrition Sciences\&Food Technology, 7(5), pp. 311-318. 